\title{
Biochemical Studies on Adenovirus Multiplication
}

\author{
XIII. Synthesis of Virus-Specific Ribonucleic Acid During \\ Infection with Human Adenovirus Type 12 \\ STANLEY MAK ${ }^{1}$ AND MAURICE GREEN ${ }^{2}$ \\ Institute for Molecular Virology, Saint Louis University School of Medicine, Saint Louis, Missouri 63110
}

Received for publication 10 June 1968

\begin{abstract}
The transcription of virus-specific ribonucleic acid (RNA) was studied in KB cells infected with adenovirus type 12 (strain Huie). Viral deoxyribonucleic acid (DNA) synthesis began at 12 to $15 \mathrm{hr}$ after infection, and virus maturation occurred between 20 and $50 \mathrm{hr}$ after infection. The rate of incorporation of ${ }^{3} \mathrm{H}$-uridine into RNA per infected cell was stimulated, reaching a maximum of 1.6 times that of uninfected cells at $20 \mathrm{hr}$ after infection. "Early" viral messenger ribonucleic acid (mRNA) constituted $0.1 \%$ of RNA synthesized at $11 \mathrm{hr}$, and "late" viral mRNA constituted $50 \%$ of RNA synthesized at $45 \mathrm{hr}$ after infection, as determined by hybridization of viral DNA with labeled RNA from infected cells pulse labeled with ${ }^{3} \mathrm{H}$-uridine. The species of virus-specific RNA synthesized at $22 \mathrm{hr}$ after infection (when virus maturation has just begun) and at $45 \mathrm{hr}$ (when virus maturation is nearly complete) were studied further: (i) 22- and 45-hr RNA had the same average guanine plus cytosine content, $47 \%$, (ii) 22 - and 45 -hr RNA contained mostly the same viral nucleotide sequences, (iii) 45-hr RNA had a five times higher concentration of virus-specific RNA molecules than did 22-hr RNA, and (iv) 22 and 45-hr RNA contained virus-specific nucleotide sequences transcribed from all, or nearly all, of the viral genome.
\end{abstract}

Human adenovirus (Ad) type 12 transforms hamster and rat embryo cells in vitro $(17,19)$, induces tumors in newborn rodents $(9,15,16$, 21 ), and produces complete virions upon infection of human cells. We have studied previously the properties of virus-specific ribonucleic acid (RNA) synthesized in Ad 12 tumor and transformed cells $(4,5,6)$. To compare the species of virus-specific RNA molecules synthesized in Ad 12 tumor and transformed cells with those transcribed during productive infection, we studied the synthesis of virus-specific RNA in Ad 12-infected KB cells. In this paper, we describe (i) the time course of synthesis of virus, viral deoxyribonucleic acid (DNA), and virusspecific RNA, (ii) some properties of "late" viral messenger ribonucleic acid (mRNA), and (iii) an estimation of the fraction of the viral genome transcribed during infection.

\footnotetext{
${ }^{1}$ Present Address: Biology Department, McMaster University, Hamilton, Ontario, Canada.

${ }^{2}$ Recipient of Research Career Award from the National Institutes of Health (5-K6-AI-4739).
}

\section{Materials AND Methods}

Cells, medium, and virus. A clonal subline of $\mathrm{KB}$ cells (11), growing exponentially in suspension in Eagle's minimal essential medium (3) with 5\% horse serum, was used for propagation of virus, the study of macromolecular synthesis on infection with Ad 12, and the plaque assay for Ad 12. The "highly" oncogenic prototype strain of Ad 12 (Huie) was employed in these studies. Stock virus consisted of 30 -fold concentrates of $60-\mathrm{hr}$ infected cells disrupted by sonic treatment in phosphate-buffered saline (PBS; 2).

Infection and labeling of cells. KB suspension cultures at $2 \times 10^{5}$ to $5 \times 10^{5}$ cells per ml were centrifuged, resuspended in growth medium at $5 \times 10^{6}$ cells per ml, and infected with $\mathrm{Ad} 12$ at an input multiplicity of 0.3 plaque-forming units per cell, corresponding to about 100 virions per cell (14). The cells were maintained in suspension for $90 \mathrm{~min}$ at $37 \mathrm{C}$ to permit virus adsorption, diluted 20 -fold in complete medium, and further incubated at $37 \mathrm{C}$. A portion was removed, and the proportion of cells surviving infection was determined by cell cloning (12). The $99 \%$ reduction in surviving cells indicated that infection was complete under the conditions used. At different times after infection, 200-ml portions of infected cells were incubated with ${ }^{3} \mathrm{H}$-uridine $(1 \mu \mathrm{c} / \mathrm{ml}$, $20 \mathrm{c} / \mathrm{mmole}$ ) for $30 \mathrm{~min}$. Incorporation was stopped 
by the addition of 0.5 volume of frozen $0.15 \mathrm{M} \mathrm{NaCl}$; the cells were collected by centrifugation, washed with cold PBS, and stored at $-20 \mathrm{C}$.

Preparation of cell RNA. Whole-cell RNA was extracted from frozen pellets of infected and uninfected cells by the hot phenol-sodium dodecyl sulfate (SDS) procedure (23) and dialyzed against $0.1 \times$ SSC (SSC $=0.15 \mathrm{~m} \mathrm{NaCl}-0.015 \mathrm{~m}$ sodium citrate). The amount of RNA was determined by the orcinol procedure (10). Recovery of RNA was 80 to $100 \%$. Unlabeled infected cell RNA used in the DNA-RNADNA hybridization experiments was purified further by treatment with deoxyribonuclease I, followed by the hot phenol-SDS procedure (23). After ether extraction and removal of the ether with nitrogen, the solution was dialyzed extensively against $0.1 \times$ SSC.

Virus growth. At various times after infection, 2-ml amounts of infected cell cultures were centrifuged; the cells were resuspended in PBS-0.1 ${ }^{\text {; }}$, bovine serum albumin (Fraction V, Armour Laboratories) and stored at $-20 \mathrm{C}$. After thawing, the cells were disrupted at $0 \mathrm{C}$ in a Raytheon DF-101 sonic oscillator at full power for $5 \mathrm{~min}$. Infectious virus was determined by the plaque assay (14).

Viral DNA synthesis. 5-Fluorodeoxyuridine (FUDR, $10^{-6} \mathrm{M}$ ) was added to portions of cell suspension at various times after infection, and the virus yield was determined at $50 \mathrm{hr}$ by the plaque assay. The final yield of virus is assumed to reflect the total viral DNA synthesized up to the time of inhibition of DNA synthesis by FUDR, as previously established with Ad 2-infected KB cells (11).

Preparation of $A d 12 D N A$. Ad 12 was grown and purified, and viral DNA was extracted as previously described (13).

Detection of virus-specific RNA. Ad 12-specific RNA was measured as ribonuclease-resistant DNARNA hybrids formed between Ad 12 DNA on nitrocellulose membrane filters and labeled RNA from infected cells. Hybridization was carried out in $2 \times$ SSC containing $0.1 \%$ SDS at $64 \mathrm{C}$ for $24 \mathrm{hr}$, essentially as described by Gillespie and Spiegelman (8). The presence of SDS did not affect the hybridization efficiency, but it reduced the nonspecific binding of ${ }^{3} \mathrm{H}-\mathrm{RNA}$ to empty membrane filters. ${ }^{3} \mathrm{H}-\mathrm{RNA}$ bound to DNA-containing filters was counted in a scintillation spectrometer, as previously described (4).

$R N A$ synthesis. At different times after infection, $100-\mathrm{ml}$ portions of suspension cultures were incubated with ${ }^{3} \mathrm{H}$-uridine $(1 \mu \mathrm{c} / \mathrm{ml}, 20 \mathrm{c} / \mathrm{mmole})$ at $37 \mathrm{C}$. At 8 , $16,24,32$, and $40 \mathrm{~min}, 10-\mathrm{ml}$ amounts were collected on membrane filters, washed with cold $0.3 \mathrm{M}$ trichloroacetic acid, dried, and counted in $10 \mathrm{ml}$ of scintillation fluid in a liquid scintillation spectrometer (Packard Instrument Co., Inc., Downers Grove, Ill.). The slope of the plot of radioactivity incorporated per cell versus time of incubation was taken as the rate of RNA synthesis.

Determination of thermal elution temperature $(T e)$ of DNA-RNA hybrids. DNA-RNA hybrids were formed between Ad 12 DNA ( $5 \mu \mathrm{g} /$ filter) and ${ }^{3} \mathrm{H}-\mathrm{RNA}$ trom cells labeled for $30 \mathrm{~min}$ with ${ }^{3} \mathrm{H}$-uridine at 22 and $45 \mathrm{hr}$ after infection. Filters containing 1,800 to 2,600 counts/min of bound ${ }^{3} \mathrm{H}$-RNA were heated in $0.1 \times \mathrm{SSC}$ for $10 \mathrm{~min}$ at various temperatures. The
${ }^{3} \mathrm{H}-\mathrm{RNA}$ released into solution at each temperature, together with $100 \mu \mathrm{g}$ of carrier calf thymus DNA, was precipitated with cold $0.3 \mathrm{~m}$ trichloroacetic acid, collected on membrane filters, dried, and counted in a scintillation spectrometer.

Determination of the extent of transcription of the viral genome. Membrane filters, containing $0.2 \mu \mathrm{g}$ of Ad 12 DNA, were annealed with increasing amounts of unlabeled RNA from Ad 12-infected KB cells in $2 \times$ SSC for $24 \mathrm{hr}$ at $64 \mathrm{C}$. After washing the filters with $2 \times \mathrm{SSC}$, treating with ribonuclease, and rewashing, one set of filters was annealed with $2 \mu \mathrm{g}$ of sonically treated, heat-denatured Ad $12{ }^{3} \mathrm{H}$-DNA in $2 \times$ SSC for $24 \mathrm{hr}$ at $64 \mathrm{C}$. This amount of ${ }^{3} \mathrm{H}-\mathrm{DNA}$ is sufficient to saturate the immobilized Ad 12 DNA. Filters were processed, as described by Warnaar and Cohen (22), and the amount of ${ }^{3} \mathrm{H}$-DNA hybridized was determined by counting in a scintillation spectrometer. The extent of the genome transcribed is inversely related to the amount of ${ }^{3} \mathrm{H}$-DNA bound. A duplicate set of filters was annealed with homologous ${ }^{3} \mathrm{H}$-RNA from Ad 12-infected KB cells in $2 \times$ SSC containing $0.1 \%$ SDS. This was performed to evaluate the degree of saturation of complementary DNA sites by the unlabeled RNA during the first reaction; the small amount of ${ }^{3} \mathrm{H}$-RNA bound was used to correct for incomplete saturation by unlabeled RNA during the first annealing reaction (7).

\section{RESULTS}

Time course of formation of intracellular virus and viral $D N A$. Virus synthesis was detected first at 20 to $24 \mathrm{hr}$ and was complete at 40 to 50 hr after infection (Fig. 1). The synthesis of viral

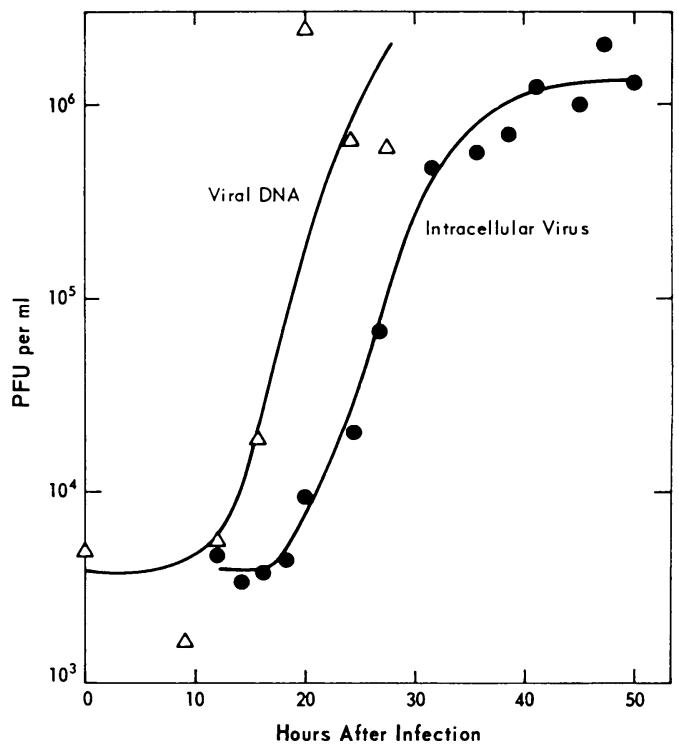

Fig. 1. Time course of formation of intracellular virus and viral DNA. Viral DNA was measured as the final yield of intracellular virus when $10^{-6} \mathrm{M}$ FUDR was added at the indicated times after infection. The experiment was repeated three times with similar results. 
DNA was determined by inhibition with FUDR. When FUDR was added at 0,9 , and $12 \mathrm{hr}$ after infection, no virus formation was detected; when added at $15 \mathrm{hr}$, a small virus increment was detected; when added later than $20 \mathrm{hr}$, normal virus yields were obtained. These results indicate that viral DNA synthesis begins at 12 to $15 \mathrm{hr}$ after infection and that the synthesis of all viral DNA molecules destined to enter infectious virions is complete within 20 to $24 \mathrm{hr}$ after infection.

Time course of synthesis of total cellular $R N A$ and virus-specific $R N A$. KB cells infected with Ad 2, 12, and 31 incorporate nearly twice the ${ }^{3} \mathrm{H}$-uridine into the acid-soluble fraction as do uninfected cells and increase their RNA content (M. Green and M. Piña, unpublished data). The rate of total RNA synthesis was stimulated by Ad 12 infection, reaching a maximal level of 1.6 times that of uninfected cells at $20 \mathrm{hr}$ after infection, as judged by the incorporation of ${ }^{3} \mathrm{H}$-uridine into the acid-insoluble fraction (Fig. 2). However, the possibility that this stimulation was due to an increased specific activity of pyrimidine precursors in the acid-soluble pool cannot be ruled out.

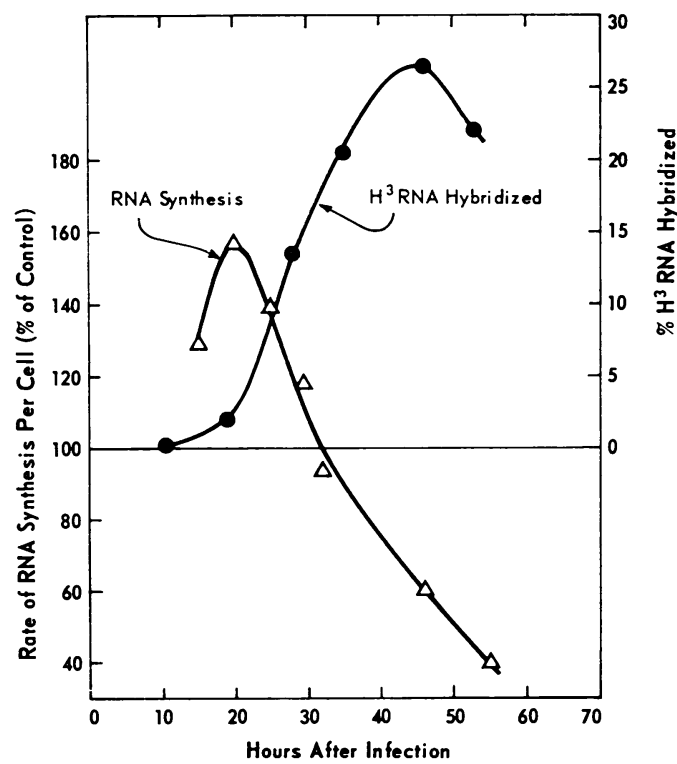

FIG. 2. Synthesis of total cellular RNA and virusspecific RNA at different times after infection. Rate of total RNA synthesis $(\triangle)$ was estimated from the incorporation of ${ }^{3} \mathrm{H}$-uridine into the acid-insoluble fraction and is plotted as percentage of uninfected control cells. Synthesis of virus-specific RNA (-) was determined by annealing $1 \mu \mathrm{g}$ of $\mathrm{Ad} 12 \mathrm{DNA}$ with ${ }^{3} \mathrm{H}-\mathrm{RNA}$ isolated from cells labeled with ${ }^{3} \mathrm{H}$-uridine at different times after infection; the percentage of the ${ }^{3} \mathrm{H}-\mathrm{RNA}$ that hybridized with viral DNA is plotted.
Virus-specific RNA synthesized at different times after infection was detected by annealing $1 \mu \mathrm{g}$ of Ad 12 DNA with ${ }^{3} \mathrm{H}-\mathrm{RNA}$ extracted from infected cells labeled for 30 min with ${ }^{3} \mathrm{H}$ uridine (Table 1, Fig. 2). ${ }^{3} \mathrm{H}-\mathrm{RNA}$ from uninfected cells did not hybridize significantly with Ad 12 DNA. In other experiments, RNA from Ad 12-infected cells $(15,000$ counts $/ \mathrm{min})$ did not hybridize significantly with $1.5 \mu \mathrm{g}$ of Pseudomonas aeruginosa DNA. At $11 \mathrm{hr}$ after infection (before viral DNA synthesis begins), only $0.1 \%$ of ${ }^{3} \mathrm{H}-\mathrm{RNA}$ hybridized with viral DNA. The proportion of labeled RNA that hybridized with viral DNA increased as infection progressed, reaching a maximum of $27 \%$ at $46 \mathrm{hr}$ after infection.

TABLE 1. Hybridization of Ad $12 \mathrm{DNA}$ with ${ }^{3} \mathrm{H}-\mathrm{RNA}$ isolated from Ad 12-infected $K B$ cells at different times after infection ${ }^{a}$

\begin{tabular}{|c|c|c|c|c|}
\hline $\begin{array}{l}\text { Time after } \\
\text { infection }\end{array}$ & $\begin{array}{c}\text { Input } \\
{ }^{3} \mathrm{H}-\mathrm{RNA}\end{array}$ & $\begin{array}{c}\text { Ad } 12 \\
\text { DNA } \\
(\mu \mathrm{g} / \text { filter })\end{array}$ & $\begin{array}{c}\text { 'H-RNA } \\
\text { bound }\end{array}$ & Bound \\
\hline$h r$ & counts/min & & counts/min & $\%$ \\
\hline 11 & 32,500 & $\begin{array}{l}1 \\
1 \\
0\end{array}$ & $\begin{array}{r}40 \\
41 \\
3\end{array}$ & $\begin{array}{l}0.12 \\
0.12 \\
0.007\end{array}$ \\
\hline 19 & 2,700 & $\begin{array}{l}1 \\
1 \\
0\end{array}$ & $\begin{array}{r}52 \\
69 \\
1\end{array}$ & $\begin{array}{l}1.9 \\
2.5 \\
0\end{array}$ \\
\hline 23 & 2,690 & $\begin{array}{l}1 \\
1 \\
0\end{array}$ & $\begin{array}{r}190 \\
176 \\
0\end{array}$ & $\begin{array}{l}7.0 \\
6.5 \\
0\end{array}$ \\
\hline 28 & 3,700 & $\begin{array}{l}1 \\
1 \\
0\end{array}$ & $\begin{array}{r}442 \\
504 \\
1\end{array}$ & $\begin{array}{c}11.9 \\
13.6 \\
0\end{array}$ \\
\hline 34 & 2,530 & $\begin{array}{l}1 \\
1 \\
0\end{array}$ & $\begin{array}{r}529 \\
505 \\
0\end{array}$ & $\begin{array}{c}20.8 \\
19.9 \\
0\end{array}$ \\
\hline 46 & 2,050 & $\begin{array}{l}1 \\
1 \\
0\end{array}$ & $\begin{array}{r}538 \\
560 \\
3\end{array}$ & $\begin{array}{c}26.2 \\
27.3 \\
0.15\end{array}$ \\
\hline 53 & 2,740 & $\begin{array}{l}1 \\
1 \\
0\end{array}$ & $\begin{array}{r}584 \\
613 \\
0\end{array}$ & $\begin{array}{c}21.3 \\
22.4 \\
0\end{array}$ \\
\hline $\begin{array}{l}\text { Uninfected } \\
\text { cells }\end{array}$ & 2,250 & $\begin{array}{l}1 \\
1 \\
0\end{array}$ & $\begin{array}{l}2 \\
1 \\
0\end{array}$ & $\begin{array}{l}0 \\
0 \\
0\end{array}$ \\
\hline
\end{tabular}

${ }^{a}$ Samples $(200 \mathrm{ml})$ of Ad 12-infected $\mathrm{KB}$ cells were pulse labeled with ${ }^{3} \mathrm{H}$-uridine $(1 \mu \mathrm{c} / \mathrm{ml}, 20$ $\mathrm{c} / \mathrm{mmole}$ ) for $30 \mathrm{~min}$ at various times after infection. ${ }^{3} \mathrm{H}-\mathrm{RNA}$ was isolated from labeled cells and annealed with Ad 12 DNA. 
Estimation of the amount of labeled virusspecific $R N A$. To determine the amount of labeled RNA that is virus-specific, it is necessary to know the efficiency of hybrid formation. Two types of experiments were performed for this purpose: (i) Different amounts of immobilized Ad 12 DNA were annealed with a constant amount of ${ }^{3} \mathrm{H}$-RNA isolated from cells at 22 and $45 \mathrm{hr}$ after infection (Fig. 3). Although $1 \mu \mathrm{g}$ of DNA binds maximal amounts of 22-hr RNA, more than $3 \mu \mathrm{g}$ of DNA is required to bind maximal amounts of 45-hr RNA. Thus, $1 \mu \mathrm{g}$ of Ad 12 DNA underestimates the amount of virusspecific RNA synthesized at late times after infection. (ii) Virus-specific RNA, purified by hybrid formation and subsequent thermal elution, was hybridized with Ad 12 DNA. Elution was carried out by heating membranes containing Ad 12 DNA-RNA hybrids in $0.1 \times \mathrm{SSC}-0.1 \%$ SDS for $10 \mathrm{~min}$ at $85 \mathrm{C}$. With four different preparations, 65 to $72 \%$ of the eluted virusspecific ${ }^{3} \mathrm{H}$-RNA hybridized with Ad 12 DNA in the first hybridization (Table 2). Another $10 \%$ of the original ${ }^{3} \mathrm{H}$-RNA input hybridized with fresh DNA filters in the second hybridization. Thus, hybrid formation under the conditions employed is about $70 \%$ efficient in detecting virus-specific RNA. In Fig. 3, 38\% of the $45-\mathrm{hr}$ ${ }^{3}$ H-RNA hybridized with Ad 12 DNA. Correcting this value for the efficiency of hybrid formation $(70 \%$, Table 2$)$, we estimated that at least $50 \%$ of the RNA synthesized during a $30-\mathrm{min}$ period at $45 \mathrm{hr}$ after infection is virus-coded.
Comparison of the virus-specific $R N A$ species at 22 and $45 \mathrm{hr}$ after infection. Virus-specific RNA synthesized at $22 \mathrm{hr}$ after infection (when viral maturation had just begun) and at 45 to $46 \mathrm{hr}$

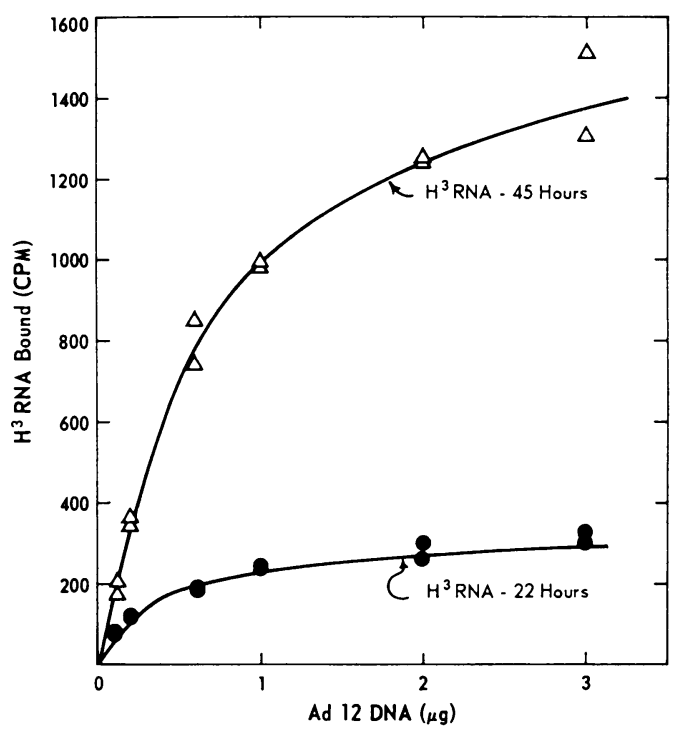

FIG. 3. The effect of the quantity of DNA on the formation of Ad 12 DNA-virus-specific $R N A$ hybrids. The binding of a constant amount of ${ }^{3} H-R N A$ to different amounts of immobilized viral DNA was determined. ${ }^{3} \mathrm{H}-\mathrm{RNA}$ was isolated from cells labeled for $30 \mathrm{~min}$ with ${ }^{3} \mathrm{H}$-uridine at $22 \mathrm{hr}, 4,600$ counts/min, (•) or $45 \mathrm{hr}, 3,660$ counts/min, $(\triangle)$ after infection.

TABLE 2. Efficiency of hybrid formation between Ad $12 \mathrm{DNA}$ and virus-specific $R N A^{a}$

\begin{tabular}{|c|c|c|c|c|c|c|}
\hline \multirow{2}{*}{ Time after infection } & \multirow{2}{*}{ Total ${ }^{3} \mathrm{H}-\mathrm{RNA}$ input" } & \multicolumn{2}{|c|}{ First hybridization } & \multicolumn{2}{|c|}{ Second hybridization } & \multirow[t]{2}{*}{$\begin{array}{l}{ }^{3} \mathrm{H}-\mathrm{R} \text { A remaining } \\
\text { in solution }\end{array}$} \\
\hline & & $\begin{array}{c}\text { Ad } 12 \\
\text { DNA } \\
(\mu g / \\
\text { filter })\end{array}$ & Bound & $\begin{array}{l}\text { Ad } 12 \\
\text { DNA }\end{array}$ & Bound & \\
\hline$h r$ & counts/min & & counts/min & $\mu \mathrm{g}$ & counts/min & counts/min \\
\hline 22 & $\begin{array}{l}1,060(100 \%) \\
1,110(100 \%) \\
1,110(100 \%)\end{array}$ & $\begin{array}{l}1 \\
1 \\
0\end{array}$ & $\begin{aligned} 750 & (70 \%) \\
795 & (72 \%) \\
6 & (0.6 \%)\end{aligned}$ & $\begin{array}{l}1 \\
1 \\
0\end{array}$ & $\begin{aligned} 91 & (9 \%) \\
69 & (7 \%) \\
2 & (0.2 \%)\end{aligned}$ & $\begin{array}{c}94(9 \%) \\
82(8 \%) \\
880(80 \%)\end{array}$ \\
\hline 45 & $\begin{array}{l}190(100 \%) \\
170(100 \%) \\
170(100 \%)\end{array}$ & $\begin{array}{l}1 \\
1 \\
0\end{array}$ & $\begin{array}{r}145(76 \%) \\
110(65 \%) \\
1\end{array}$ & $\begin{array}{l}1 \\
1 \\
0\end{array}$ & $\begin{aligned} 19 & (10 \%) \\
21 & (12 \%) \\
4 & (2 \%)\end{aligned}$ & $\begin{aligned} 23 & (12 \%) \\
23 & (13 \%) \\
170 & (100 \%)\end{aligned}$ \\
\hline
\end{tabular}

${ }^{a}{ }^{3} \mathrm{H}$-RNA was released from filters containing Ad 12 DNA-virus-specific ${ }^{3} \mathrm{H}$-RNA hybrids by heating in $0.1 \times \mathrm{SSC}-0.1 \% \mathrm{SDS}$ at $85 \mathrm{C}$ for $10 \mathrm{~min}$. This treatment releases more than $90 \%$ of the ${ }^{3} \mathrm{H}-\mathrm{RNA}$. Released ${ }^{3} \mathbf{H}$-RNA was then annealed sequentially with two DNA-containing filters. The ${ }^{3} \mathbf{H}-\mathrm{RNA}$ bound after the first and second hybridization are given above.

${ }^{b}{ }^{3} \mathrm{H}-\mathrm{RNA}$ input and ${ }^{3} \mathrm{H}$-RNA remaining in solution were determined by precipitating a portion of the solution with $100 \mu \mathrm{g}$ of carrier DNA with $0.3 \mathrm{M}$ trichloroacetic acid on membrane filters, counting in a scintillation spectrometer, and correcting for the lower counting efficiency of trichloroacetic acid precipitated sample ( 0.70 of ${ }^{3} \mathrm{H}$-RNA air-dried on membrane filters). 
after infection (when viral maturation was nearly complete) was studied further. At these times about $5 \%$ and 35 to $40 \%$, respectively, of the RNA labeled during 30 min hybridized with $3 \mu \mathrm{g}$ of viral DNA (Fig. 3). Virus-specific RNA molecules synthesized both at 22 and $45 \mathrm{hr}$ fall into the category of "late" viral mRNA, since they are formed after viral DNA synthesis has begun. "Early" viral mRNA is more difficult to study because of the small amounts of this material formed $(0.1 \%$ at $11 \mathrm{hr})$.

Thermal elution profile of DNA-RNA hybrids. Bolton and McCarthy (1) have shown that the Te (the temperature at which one half of labeled RNA is released from the DNA-RNA hybrid) of DNA-RNA hybrids formed between Escherichia coli DNA and mRNA is proportional to the guanine plus cytosine content of the RNA. We found a similar relationship with virus-specific RNA isolated from cells transformed by, and lytically infected with, seven different adenovirus $(6 ;$ D. C. Thomas and M. Green, unpublished data). The Te profiles of DNA-RNA hybrids formed with 22-hr and 45-hr virusspecific RNA are very similar (Fig. 4). Te

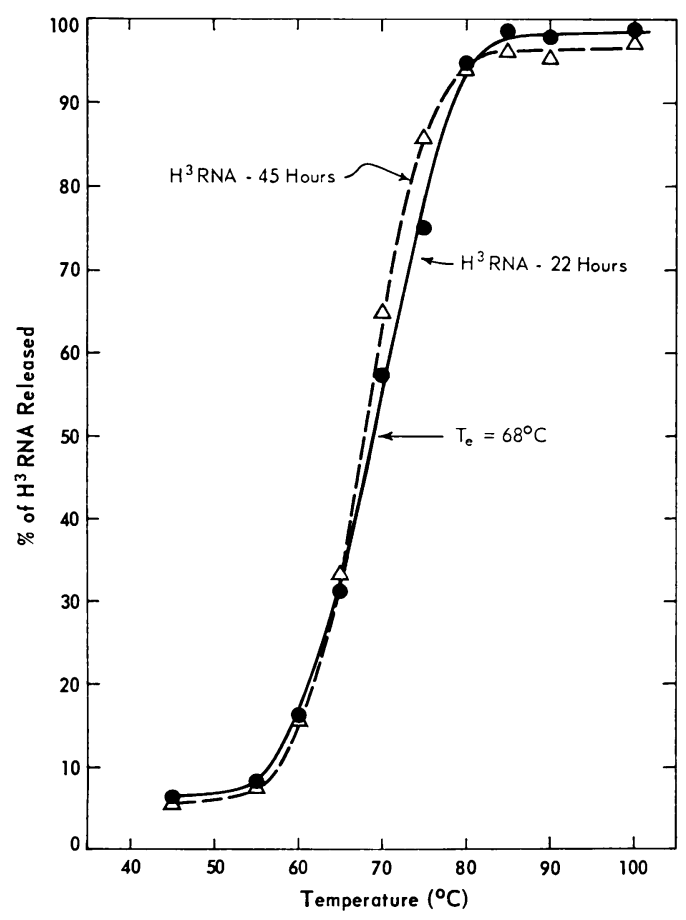

FIG. 4. Thermal elution profiles of $D N A-R N A$ hybrids on nitrocellulose membrane filters. Hybrids formed between Ad $12 \mathrm{DNA}(5 \mu \mathrm{g})$ and $22-\mathrm{hr},{ }^{3} \mathrm{H}-\mathrm{RNA}$, 2,600 counts/min, (๑) and 45-hr ${ }^{3} \mathrm{H}-\mathrm{RNA}, 1,800$ counts/min, $(\triangle)$ were heated in $0.1 \times S S C-0.1 \%$ $S D S$ at increasing temperatures; the amount of ${ }^{3} \mathrm{H}-\mathrm{RNA}$ eluted was plotted against temperatures. values of DNA-RNA hybrids formed with 22-, 23-, 25-, 45-, and 46-hr RNA are close to $68 \mathrm{C}$ (Table 3), corresponding to an average guanine plus cytosine content of $47 \%$.

Saturation of viral DNA with ${ }^{3} H-R N A$. Increasing amounts of 22 - and $45-\mathrm{hr}{ }^{3} \mathrm{H}-\mathrm{RNA}$ were annealed with a constant amount of Ad 12 DNA, and the extent of binding was determined (Fig. 5). The initial slope of 45-hr RNA is steeper than that of 22-hr RNA, indicating that the former has a higher content of labeled virusspecific RNA than the latter. Saturation of $0.2 \mu \mathrm{g}$ of Ad 12 DNA with 45-hr RNA occurred at 300 counts/min, with an input of about 17,000 counts $/ \mathrm{min}$. Saturation of the same amount of Ad 12 DNA with 22-hr RNA was not accomplished with inputs up to 300,000 counts $/ \mathrm{min}$, suggesting that some virus-specific RNA species labeled at $22 \mathrm{hr}$ after infection are present in very low concentrations.

Hybridization-competition between 22-hr RNA and 46-hr RNA. The relationship between 22-hr and 46-hr virus-specific RNA molecules was analyzed by competition for sites on viral DNA. High concentrations of unlabeled 22- and 46-hr RNA block completely the binding of both 22 and $46-\mathrm{hr}{ }^{3} \mathrm{H}-\mathrm{RNA}$ to viral DNA (Fig. 6). These results suggest that all, or nearly all, of the virusspecific RNA species synthesized at $46 \mathrm{hr}$ are present at $22 \mathrm{hr}$ and vice versa. However, if some species of virus-specific ${ }^{3} \mathrm{H}-\mathrm{RNA}$ are present at low level (insufficient to saturate all DNA sites), differences in RNA species may escape detection by hybridization-competition experiments. Although 46-hr ${ }^{3} \mathrm{H}-\mathrm{RNA}$ saturated DNA sites under these conditions, 22-hr ${ }^{3} \mathrm{H}-\mathrm{RNA}$ did not

TABLE 3. Thermal elution temperature (Te) of $A d$ $12 D N A$-virus-specific $R N A$ hybrids ${ }^{a}$

\begin{tabular}{c|c|c|c}
\hline Expt no. & $\begin{array}{c}\text { Ad 12 specific } \\
\text { RNA (time } \\
\text { after infection }\end{array}$ & $\begin{array}{c}\text { Te in } 0.1 \\
\times \text { SSC }\end{array}$ & $\begin{array}{c}\text { Avg guanine } \\
\text { plus cy tosine }^{b}\end{array}$ \\
\hline 1 & $h r$ & $C$ & $\%$ \\
22 & 68 & 47 \\
25 & 68 & 47 \\
& 23 & 67 & 46 \\
3 & 45 & 68 & 47 \\
& 25 & 68 & 47 \\
& 46 & 66 & 45 \\
\hline
\end{tabular}

${ }^{a}$ "H-RNA, isolated from cells labeled with ${ }^{3} \mathrm{H}$-uridine at the indicated times after infection, was annealed with $5 \mu \mathrm{g}$ of immobilized Ad 12 DNA. The Te of the resulting hybrid was determined.

${ }^{b}$ Estimated from graph of guanine plus cytosine versus Te of Bolton and McCarthy (1) for $E$. coli DNA-mRNA hybrids. 


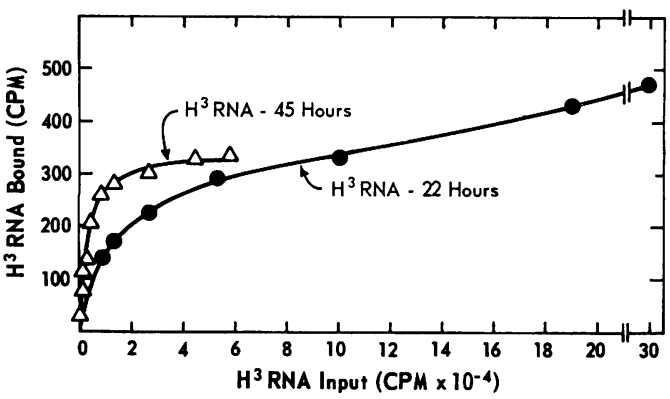

FIG. 5. Saturation of viral DNA with virus-specific ${ }^{3} \mathrm{H}-\mathrm{RNA}$. Increasing amounts of ${ }^{3} \mathrm{H}-\mathrm{RNA}$ from cells labeled for $30 \mathrm{~min}$ with ${ }^{3} \mathrm{H}$-uridine at $22 \mathrm{hr}(\bullet)$ and $45 \mathrm{hr}(\triangle)$ after infection were annealed with $0.2 \mu \mathrm{g}$ of Ad 12 DNA. The extent of ${ }^{3} \mathrm{H}-\mathrm{RNA}$ bound is plotted against input ${ }^{3} \mathrm{H}-\mathrm{RN} A$.

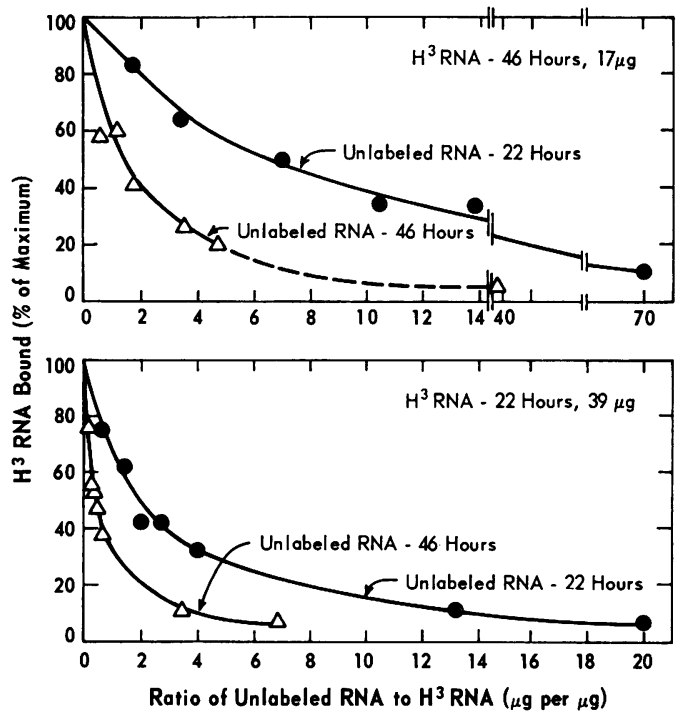

FIG. 6. Hybridization-competition analysis of 22-hr and 46-hr virus-specific RNA. Top: $17 \mu \mathrm{g}(8,000$ counts/min) of $46-h r^{3} \mathrm{H}-\mathrm{RNA}$, together with increasing amounts of unlabeled 22-hr or 46-hr RNA, was annealed with $0.2 \mu \mathrm{g}$ of immobilized viral DNA. Maximal counts/ min bound was $180(100 \%)$. Bottom: $39 \mu \mathrm{g}(46,000$ counts/min) of $22-h r^{3} \mathrm{H}-\mathrm{RNA}$, together with increasing amounts of unlabeled 22-hr or 46-hr RNA, was annealed with $0.2 \mu \mathrm{g}$ of immobilized viral DNA. Maximal counts/min bound was 220 (100\%).

(Fig. 5). Therefore, these experiments do not rule out the possibility that some minor RNA species synthesized at $22 \mathrm{hr}$ after infection were absent at $46 \mathrm{hr}$.

Relative amount o, virus-specific RNA present at 22 and $46 \mathrm{hr}$ after infection. Unlabeled 46-hr RNA competed more effectively against both 22- and 46-hr ${ }^{3} \mathrm{H}-\mathrm{RNA}$ than did unlabeled $22-\mathrm{hr}$ RNA (Fig. 6), indicating that 46-hr RNA con- tains a higher concentration of virus-specific RNA molecules than does 22-hr RNA. The relative amounts of virus-specific RNA present in unlabeled 22- and 46-hr RNA can be estimated by replotting the data of Fig. 6 as shown in Fig. 7. The slopes of the lines are proportional to the fraction of virus-specific RNA in each preparation, as shown below: The amount of radioactivity bound to DNA, i.e., ${ }^{3} \mathrm{H}-\mathrm{RNA}$ bound (counts $/ \mathrm{min}$ ), in the presence of added unlabeled virus-specific RNA is proportional to the specific activity of virus-specific RNA and can be expressed as follows:

${ }^{3} \mathrm{H}-\mathrm{RNA}$ bound (counts/min)

$$
=K \cdot \frac{f \cdot{ }^{3} \mathrm{H}-\mathrm{RNA}(\text { count } / \mathrm{min})}{f 1\left[{ }^{3} \mathrm{H}-\mathrm{RNA}\right]+f 2[\mathrm{RNA}]}
$$

where ${ }^{3} \mathrm{H}-\mathrm{RNA}$ (counts $/ \mathrm{min}$ ) = total input counts $/ \mathrm{min},\left[{ }^{3} \mathrm{H}-\mathrm{RNA}\right]=\mu \mathrm{g}$ of labeled RNA, [RNA] $=\mu \mathrm{g}$ of added unlabeled RNA, $f=$ fraction of radioactivity in ${ }^{3} \mathrm{H}-\mathrm{RNA}$ (counts/ min) which is virus-specific, $f \mathbf{1}=$ fraction of [ ${ }^{3} \mathrm{H}$-RNA] which is virus-specific, $f 2=$ fraction of [RNA] which is virus-specific, and $K=$ proportionality constant. Taking the reciprocal of the above, we obtain

$$
\begin{aligned}
& \left.1 /\left[{ }^{3} \mathrm{H}-\mathrm{RNA} \text { bound (counts } / \mathrm{min}\right)\right] \\
& \qquad=K 1 \cdot f 1+K 1 \cdot f 2[\mathrm{RNA}] /\left[{ }^{3} \mathrm{H}-\mathrm{RNA}\right]
\end{aligned}
$$

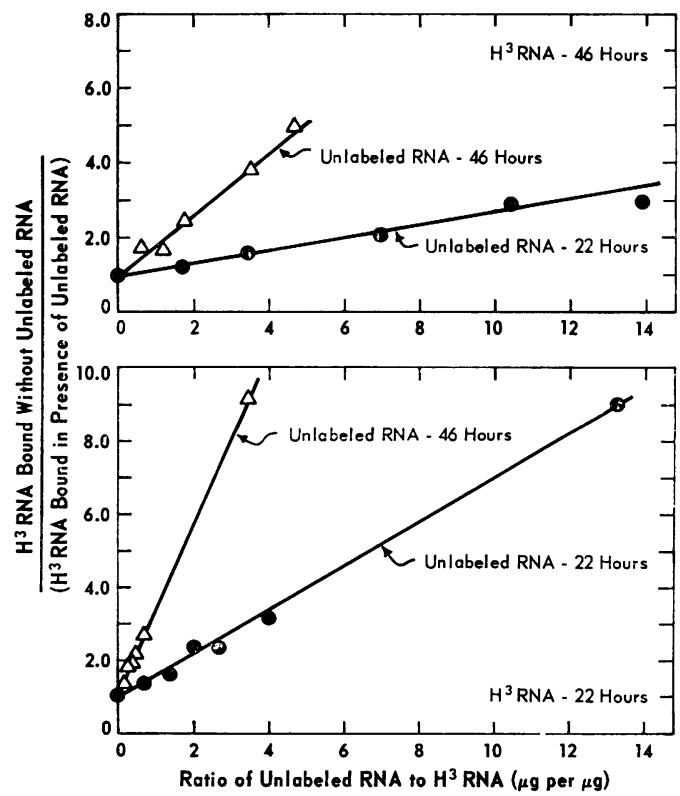

FIG. 7. Replot of data from Fig. 6 to determine the relative proportion of virus-specific RNA in unlabeled 22- and 46-hr RNA. 
where $K 1=\left[{ }^{3} \mathrm{H}-\mathrm{RNA}\right] /\left[K \cdot f \cdot{ }^{3} \mathrm{H}-\mathrm{RNA}\right.$ (counts $\min )]$ and [ $\left.{ }^{3} \mathrm{H}-\mathrm{RNA}\right]$ and ${ }^{3} \mathrm{H}-\mathrm{RNA}$ (counts/min) are constants, since the same amount of labeled RNA is used throughout each experiment. A plot of $1 /\left[{ }^{3} \mathrm{H}-\mathrm{RNA}\right.$ bound (counts / $\mathrm{min}$ )] [RNA]/ [ $\left.{ }^{3} \mathrm{H}-\mathrm{RNA}\right]$ will yield a straight line with a slope proportional to $f 2$, the fraction of the unlabeled RNA which is virus-specific. In Fig. 7, for convenience in plotting, the relative amount of ${ }^{3} \mathrm{H}-\mathrm{RNA}$ bound, i.e., [ ${ }^{3} \mathrm{H}-\mathrm{RNA}$ bound without unlabeled RNA] $/\left[{ }^{3} \mathrm{H}-\mathrm{RNA}\right.$ bound in the presence of unlabeled RNA], is plotted against [RNA] [ ${ }^{3} \mathrm{H}$-RNA]. The validity of this plot was checked by reconstruction experiments in which $f 2$ was altered by the addition of known amounts of RNA from uninfected cells to the unlabeled RNA from infected cells; a change in $f 2$ produced a corresponding change in slope. From the ratios of the slopes (Fig. 7), we estimated that 46-hr RNA contains five times more virus-specific RNA than does 22-hr RNA.

The fraction of the viral genome transcribed during infection. The DNA-RNA-DNA hybridization procedure for estimating the fraction of the viral genome transcribed is described in detail elsewhere (7). In essence, two sequential annealing reactions were used. In the first reaction, immobilized viral DNA was hybridized with saturating amounts of unlabeled virus-specific RNA. In the second reaction, prehybridized viral DNA was annealed with labeled viral DNA. The amount of viral DNA bound was inversely related to the fraction of the viral genome transcribed to virus-specific RNA.

Increasing amounts of unlabeled RNA, isolated from cells at 22 and $45 \mathrm{hr}$ after infection, were annealed with $0.2 \mu \mathrm{g}$ of immobilized Ad 12 DNA. Viral DNA presaturated with virus-specific RNA was then annealed with saturating amounts of viral ${ }^{3} \mathrm{H}$-DNA to determine the fraction of the immobilized viral DNA not complementary to virus-specific RNA (Table 4, Fig. 8). Annealing viral DNA with 500 and $1,000 \mu \mathrm{g}$ of unlabeled RNA from infected cells reduced the subsequent binding of ${ }^{3} \mathrm{H}$-DNA to 54 to $58 \%$ of that of untreated DNA filters. The binding of homologous ${ }^{3} \mathrm{H}-\mathrm{RNA}$ after the first reaction was reduced to 13 to $17 c_{c}$ of that of untreated membranes, providing quantitative data for correcting the incomplete saturation with unlabeled virusspecific RNA (Table 4, Fig. 8). Some preparations of uninfected KB cell RNA inhibited DNA binding nonspecifically by $20, c$ at $2 \mathrm{mg}$ per filter and $10 r_{c}$ at 1 to $2 \mathrm{mg}$ per filter (Fig. 8). This is not a problem, since a plateau was reached with $0.5 \mathrm{mg}$ or less of unlabeled RNA (Fig. 8). Close to $50 \%$ of viral DNA is complementary to virusspecific RNA present at 22 and $46 \mathrm{hr}$ after infec-
TABLE 4. Hybridization of viral ${ }^{3} \mathrm{H}-\mathrm{DNA}$ and virusspecific ${ }^{3} \mathrm{H}-\mathrm{RNA}$ to $\mathrm{Ad} 12 \mathrm{DNA}$ after annealing with unlabeled 45-hr infected cell $R N A^{a}$

\begin{tabular}{|c|c|c|c|c|c|}
\hline \multicolumn{2}{|c|}{ First annealing } & \multicolumn{4}{|c|}{$\begin{array}{c}\text { Second annealing with either }{ }^{3} \mathrm{H}-\mathrm{DNA} \\
\text { or }{ }^{3} \mathrm{H}-\mathrm{R} N \mathrm{~A}\end{array}$} \\
\hline \multirow[b]{2}{*}{$\begin{array}{c}\text { Unlabeled } \\
\text { RAA }\end{array}$} & \multirow[b]{2}{*}{$\begin{array}{l}\text { Ad } 12 \\
\text { DNA ( } \mu \mathrm{g} \\
\text { /filter })\end{array}$} & \multicolumn{2}{|c|}{${ }^{3} \mathrm{H}-\mathrm{DNA}$ bound } & \multicolumn{2}{|c|}{${ }^{3}$ H-RNA bound } \\
\hline & & $\begin{array}{l}\text { Radio- } \\
\text { activity }\end{array}$ & $\begin{array}{l}\text { Per cent } \\
\text { of maxi- } \\
\text { mum }\end{array}$ & $\begin{array}{l}\text { Radio- } \\
\text { activity }\end{array}$ & $\begin{array}{l}\text { Per cent } \\
\text { of maxi- } \\
\text { mum }\end{array}$ \\
\hline$\mu g$ & & counts/min & & $\underset{\min }{\text { counts/ }}$ & \\
\hline None & $\begin{array}{l}0.2 \\
0.2 \\
0.2 \\
0.2 \\
0 \\
0\end{array}$ & $\left.\begin{array}{r}1,571 \\
1,549 \\
1,618 \\
1,510 \\
14 \\
10\end{array}\right\}$ & 100 & $\left.\begin{array}{l}263 \\
217\end{array}\right\}$ & 100 \\
\hline 60 & $\begin{array}{l}0.2 \\
0.2 \\
0\end{array}$ & $\begin{array}{r}987 \\
953 \\
11\end{array}$ & $\begin{array}{l}63 \\
61\end{array}$ & $\begin{array}{r}64 \\
57 \\
1\end{array}$ & $\begin{array}{l}27 \\
24\end{array}$ \\
\hline 240 & $\begin{array}{l}0.2 \\
0.2 \\
0\end{array}$ & $\begin{array}{r}919 \\
941 \\
6\end{array}$ & $\begin{array}{l}59 \\
60\end{array}$ & $\begin{array}{r}44 \\
47 \\
0\end{array}$ & $\begin{array}{l}18 \\
19\end{array}$ \\
\hline 500 & $\begin{array}{l}0.2 \\
0.2 \\
0\end{array}$ & $\begin{array}{r}910 \\
852 \\
8\end{array}$ & $\begin{array}{l}58 \\
54\end{array}$ & $\begin{array}{r}42 \\
37 \\
0\end{array}$ & $\begin{array}{l}17 \\
15\end{array}$ \\
\hline 1,000 & $\begin{array}{l}0.2 \\
0.2 \\
0\end{array}$ & $\begin{array}{r}849 \\
854 \\
11\end{array}$ & $\begin{array}{l}54 \\
54\end{array}$ & $\begin{array}{r}30 \\
37 \\
0\end{array}$ & $\begin{array}{l}13 \\
15\end{array}$ \\
\hline
\end{tabular}

${ }^{a}$ Nitrocellulose membrane filters containing $0.2 \mu \mathrm{g}$ of Ad 12 DNA were annealed with increasing amounts of unlabeled RNA isolated from KB cells at $45 \mathrm{hr}$ after infection in the first reaction. Duplicate DNA filters were then annealed with (i) ${ }^{3} \mathrm{H}$-DNA $(2 \mu \mathrm{g}, 16,400$ counts $/ \mathrm{min})$ to determine the fraction of DNA sites remaining unhybridized ( $D$ in legend to Table 5), and (ii) ${ }^{3} \mathrm{H}$ RNA from 45-hr infected cells to determine the fraction of complementary DNA sites not saturated by unlabeled RNA ( $R$ in legend to Table 5). The latter hybridization is necessary to correct for the "incomplete" saturation of DNA sites by complementary RNA (7).

tion (Table 5). These results suggest that probably the whole genome is transcribed, since most likely only one strand of each gene is involved.

\section{Discussion}

The synthesis of early Ad 12-specific RNA is barely detectable at $11 \mathrm{hr}$ after infection. (Viral DNA synthesis begins between 12 and $15 \mathrm{hr}$ after infection.) In contrast, late virus-specific RNA constitutes about $50 \%$ of 30-min labeled RNA at $46 \mathrm{hr}$ after infection. Thus, the rate of late viral mRNA synthesis at 19 to $46 \mathrm{hr}$ after infec- 
tion is about 20 to 200 times that of early mRNA synthesis (11 hr after infection). A similar pattern is found in Ad 2-infected KB cells (20). In contrast, the rates of synthesis of late and early

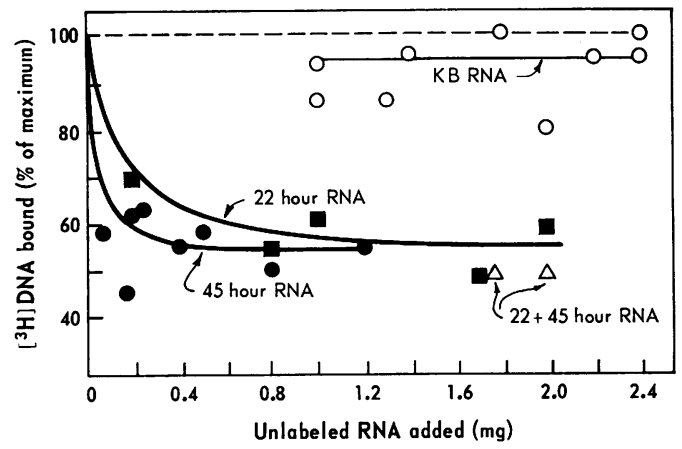

FIG. 8. Determination of the unhybridized fraction of viral DNA after presaturation with virus-specific RNA. Amounts $(0.2 \mu \mathrm{g})$ of viral DNA immobilized on membrane filters were annealed first with different amounts of unlabeled RNA from the following sources: (i) $K B$ cells, 22 hr after infection with $A d 12$, (ii) $K B$ cells, $45 \mathrm{hr}$ after infection with Ad 12, (iii) uninfected $K B$ cells. Filters containing DNA-RNA hybrids and unreacted DNA were annealed further with saturating amounts $(2 \mu g)$ of sonically treated, denatured, viral ${ }^{3} \mathrm{H}-\mathrm{DNA}$, and the extent of binding was determined. The points of 22-hr RNA, 45-hr RNA, and KB RNA are from two, three, and three different experiments, respectively; each experiment utilized a different $R N A$ preparation.

TABLE 5. Fraction of the viral genome complementary to virus-specific $R N A^{a}$

\begin{tabular}{c|c|c|c}
\hline \multicolumn{2}{c|}{ Unlabeled RNA, 22 hr } & \multicolumn{2}{|c}{ Unlabeled RNA, 45 hr } \\
\cline { 1 - 2 } Expt 1 & Expt 2 & Expt 1 & Expt 2 \\
\hline $0.45^{b}$ & 0.51 & 0.55 & 0.50 \\
0.48 & 0.58 & 0.54 & 0.49 \\
0.56 & & & 0.53 \\
\hline
\end{tabular}

${ }^{a}$ Values listed within each experiment represent different filters annealed with saturating amounts of unlabeled virus-specific RNA. The average values obtained at $22 \mathrm{hr}$ in experiment 1 was 0.50 and in experiment 2 was 0.55 ; at $45 \mathrm{hr}$, the average values in experiment 1 was 0.54 and 0.51 in experiment 2.

${ }^{b}$ Each value was calculated using the following relationship: $T=(1-D) /(1-R)$ where $T=$ the fraction of the viral genome complementary to virus-specific RNA, $D=$ the fraction of the ${ }^{3} \mathrm{H}$ DNA bound to DNA during the second annealing reaction after presaturation with unlabeled RNA to that bound without presaturation with unlabeled RNA, and $R=$ the fraction of the ${ }^{3} \mathrm{H}$ RNA bound to DNA after presaturation with unlabeled RNA to that bound without presaturation with unlabeled RNA (7).
mRNA in vaccinia virus infected HeLa cells are similar (18).

The cellular content of virus-specific RNA at $45 \mathrm{hr}$ is five times that at $22 \mathrm{hr}$ after infection. The inability of 22-hr RNA (at the levels employed), to saturate DNA sites suggests that some species of virus-specific RNA are synthesized at low rates at this time. But mostly the same species of virus-specific RNA molecules are transcribed at 22 and $45 \mathrm{hr}$ after infection, since unlabeled 22-hr RNA effectively competes with 45-hr ${ }^{3} \mathrm{H}$-RNA for sites on viral DNA and vice versa. Furthermore, DNA-RNA hybrids formed with 22-hr and 45-hr RNA possess almost identical melting profiles and the same guanine plus cytosine content. In addition, the virus-specific RNA molecules present at both 22 and $45 \mathrm{hr}$ after infection are complementary to about $50 \%$ of the Ad 12 genome. Thus, the equivalent of one DNA strand is transcribed from the time virus maturation begins to the time of maximal virus yields. It is not known how much of the viral genome is transcribed prior to viral DNA synthesis.

\section{ACKNOWLEDGMENTS}

This investigation was supported by Public Health Service grant AI-01725, contract PH43-64-928 from the National Institute of Allergy and Infectious Diseases, and contract PH43-67-692 from the National Cancer Institute.

\section{Literature Cited}

1. Bolton, E. T., and B. J. McCarthy. 1964. Fractionation of complementary RNA. J. Mol. Biol. 8:201-209.

2. Dulbecco, R., and M. Vogt. 1954. Plaque formation and isolation of pure lines with poliomyelitis viruses. J. Exptl. Med. 99:167-182.

3. Eagle, H. 1959. Amino acid metabolism in mammalian cell cultures. Science 130:432-437.

4. Fujinaga, K., and M. Green. 1966. The mechanism of viral carcinogenesis by DNA mammalian viruses. I. Viral-specific RNA in polyribosomes of adenovirus tumor and transformed cells. Proc. Natl. Acad. Sci. U.S. 55:1567-1574.

5. Fujinaga, K., and M. Green. 1967. Mechanism of viral carcinogenesis by deoxyribonucleic acid mammalian viruses. IV. Related virus-specific ribonucleic acids in tumor cells induced by "highly" oncogenic adenovirus types 12,18 , and 31. J. Virology $1: 576-582$.

6. Fujinaga, K., and M. Green. 1968. Mechanism of viral carcinogenesis by DNA mammalian viruses. V. Properties of purified viral-specific RNA from human adenovirus-induced tumor cells. J. Mol. Biol. 31 :63-73.

7. Fujinaga, K., S. Mak, and M. Green. 1968. A method for determining the fraction of the viral genome transcribed during infection and its application to adenovirus infected cells. Proc. Natl. Acad. Sci. U.S. 60:959-966. 
8. Gillespie, D., and S. Spiegelman. 1965. A quantitative assay for DNA-RNA hybrids with DNA immobilized on a membrane. J. Mol. Biol. 12 :829-842.

9. Girardi, A. J., M. R. Hilleman, and R. E. Zwickey. 1964. Tests in hamsters for oncogenic quality of ordinary viruses including adenovirus type 7 (29138). Proc. Soc. Exptl. Biol. Med. 115:1141-1150.

10. Green, M. 1959. Biochemical studies on adenovirus multiplication. I. Stimulation of phosphorus incorporation into DNA and RNA. Virology 9:343-359.

11. Green, M. 1962. Biochemical studies on adenovirus multiplication. III. Requirement for DNA synthesis. Virology 18:601-613.

12. Green, M., and G. E. Daesch. 1961. Biochemical studies on adenovirus multiplication. II. Kinetics of nucleic acid and protein synthesis in suspension cultures. Virology 13:169-176.

13. Green, M., and M. Piña. 1964. Biochemical studies on adenovirus multiplication. VI. Properties of highly purified tumorigenic human adenoviruses and their DNA's. Proc. Natl. Acad. Sci. U.S. 51:1251-1259.

14. Green, M., M. Piña, and R. Kimes. 1967. Biochemical studies on adenovirus multiplication. XII. Plaquing efficiencies of purified human adenoviruses. Virology $31: 562-565$.

15. Huebner, R. J., W. P. Rowe, and W. T. Lane. 1962. Oncogenic effects in hamsters of human adenovirus types 12 and 18. Proc. Natl. Acad. Sci. U.S. 48:2051-2058.

16. Huebner, R. J., M. J. Casey, R. M. Chanock, and K. Schell. 1965. Tumors induced in hamsters by a strain of adenovirus type 3 : sharing of tumor antigens and "neoantigens" with those produced by adenovirus type 7 tumors. Proc. Natl. Acad. Sci. U.S. 54:381-388.

17. MacBride, W. D., and A. Wiener. 1964. In vitro transformation of hamster kidney cells by human adenovirus type 12. Proc. Soc. Exptl. Biol. Med. 115:870-874.

18. Oda, K. I., and W. K. Joklik. 1967. Hybridization and sedimentation studies on "early" and "late" vaccinia messenger RNA. J. Mol. Biol. 27:395-419.

19. Pope, J. H., and W. P. Rowe. 1964. Immunofluorescent studies of adenovirus 12 tumors and of cells transformed or infected by adenoviruses. J. Exptl. Med. 120:577-588.

20. Thomas, D. C., and M. Green. 1966. Biochemical studies on adenovirus multiplication. XI. Evidence of a cytoplasmic site for the synthesis of viral-coded proteins. Proc. Natl. Acad. Sci. U.S. 56 :243-246.

21. Trentin, J. J., Y. Yabe, and G. Taylor. 1962. The quest for human cancer viruses: a new approach to an old problem reveals cancer induction in hamsters by human adenovirus Science 137 :835-841.

22. Warnaar, S. O., and J. A. Cohen. 1966. A quantitative assay for DNA-DNA hybrids using membrane filters. Biochem. Biophys. Res. Commun. 24:554-558.

23. Warner, J. R., R. Soeiro, H. C. Birnboim, M. Girard, and J. E. Darnell. 1966. Rapidly labeled HeLa cell nuclear RNA. I. Identification by zone sedimentation of a heterogeneous fraction separate from the ribosomal precursor RNA. J. Mol. Biol. 19:349-361. 